\title{
Effect of Strategic Product Development Practices on Competitiveness of Kenyan Tea in the Global Market
}

\section{Esther Wanjiru Maina ${ }^{1 *}$, Fred Mugambi ${ }^{2}$ and Esther Waiganjo ${ }^{2}$}

${ }^{1}$ School of Business, Karatina University, Karatina, Kenya

${ }^{2}$ College of Human Resource Development, Jomo Kenyatta University of Agriculture and Technology, Nairobi, Kenya

\begin{abstract}
Kenyan black CTC tea is applauded globally as a high quality product available all year round and sold as a blend and not as an original tea. The core objective of the study was to examine the effect of strategic product development practices on competiveness of Kenyan Tea in the global market. The study used cross-sectional survey design. The target population comprised of all 189 members of the East Africa Tea Trade Association (EATTA) who participate in the tea auction at Mombasa. Stratified sampling technique was used to select the study sample. Purposive sampling technique was used to select the managers who represented both the small-scale and large-scale producers. The sample was obtained using Slovin's formula (1960); $n=N /\left(1+\mathrm{Ne}^{2}\right)$. Structured and unstructured questionnaire was used to collect primary data. Pilot study tested for the validity and reliability. Cronbach's Coefficient Alpha (a) was used to determine internal consistency. Collected data was analysed using SPSS to generate descriptive and inferential statistics. Pearson correlation coefficient $(r)$ was derived while coefficient of determination $\left(R^{2}\right)$ was used to measure the amount of variation of the variables. The study findings indicated weak positive relationship of $31.0 \%$ between Strategic Product Development practices and Competitiveness. The study revealed that $1 \%$ change in Strategic product development practices decreased competitiveness of Kenyan in the global market by 0.089 units. Hence the conclusion that competitiveness of Kenyan Tea in the global market was influenced by other factors other than strategic product development Practices. The study recommended that other than strategic product development practices, the Kenyan Tea industry players should diverge from a long linear supply chain to a value network in order to make Tea a 'hero' crop and enable creation of a more sustainable industry and counter the escalating global competition.
\end{abstract}

Keywords: Strategic product development; Competitiveness; Strategic management practices

\section{Introduction}

Product development is a strategy adopted by a company to create new products that target its existing markets to achieve business growth and expansion. This practice strategically involves extending the product range through value addition, product differentiation, standardization and diversification to the existing products. Jaffee [1] noted that Strategic product development is based on how much the producer has to adjust the product on the standardization-adaptation continuum to differing market conditions.

\section{Statement of the problem}

Tea in its traditional form as a brewed beverage need to undergo change to suit the changes in consumer preferences and lifestyles and cope with increasing competition from other beverages in the global market [2]. Kenyan tea remains largely unknown in the global market for the reason that it is exported in bulk and is popularly used to blend other teas and then packed using different brands. Consequently, the Kenyan tea loses traceability and visibility in the shelves in the global market. Kenyan teas which are of high quality has not been standardized thus creating room for further manipulation by the buyers whereby the tea is normally used for blending with the cheap teas of low quality to meet the customers preferences. The blended tea fails to indicate the point of origin of the teas making the Kenyan teas loose competitiveness in the global market. A study by Omari [3] concluded that Kenya's tea has very low product diversification and value addition compared to competitors contributing to poor performance globally [4]. Tea directorate noted that Kenya exports over $99 \%$ of her tea as black CTC of which $88 \%$ is exported in bulk form while the rest as value added tea an indication that there is limited value addition and product range. This scenario amplified the need to carry out this study which concentrated on the effect of strategic product development practices on competitiveness of Kenyan Tea in the global market [5-7].

\section{Purpose of the paper}

The purpose of this paper was to evaluate the effect of strategic product development practices on competitiveness of Kenyan tea in the global market.

\section{Literature Review}

The study was guided by new trade theory and the product lifecycle theory. New trade theory was developed by Krugman in the late 1970s and early 1980s. This theory recognized that countries producing similar goods and services continue to engage in trade with one another. The theory advised that globalization, costs of economies of scale and specialization as factors that contribute to growth and expansion of businesses for developing nations. According to this theory, early entrants in a given industry have an inherent advantage in that industry [8]. They have more time to attain economies of scale making it difficult for new firms to compete. Thus, emerging industries in developing nations have a hard time ever becoming established in the existing global market, as the developed world has already

*Corresponding author: Mania EW, School of Business, Karatina University, Karatina, Kenya, Tel: +254 726 724123; E-mail: emainah2006@gmail.com

Received January 13, 2018; Accepted February 13, 2018; Published February 20, 2018

Citation: Maina EW, Mugambi F, Waiganjo E (2018) Effect of Strategic Product Development Practices on Competitiveness of Kenyan Tea in the Global Market. Bus Eco J 9: 340. doi: 10.4172/2151-6219.1000340

Copyright: ( $) 2018$ Maina EW, et al. This is an open-access article distributed under the terms of the Creative Commons Attribution License, which permits unrestricted use, distribution, and reproduction in any medium, provided the original author and source are credited. 
established economies of scale and often dominated the market [9]. This theory supports the study objective and its relevance was that, Kenya specializes on production of high quality black CTC which is exported to few key traditional markets making the country the leading world exporter of black CTC tea. On the other hand, the country trades the teas with China, Sri-Lanka and India. The aforementioned countries make some of the consumers of the Kenyan tea and yet they produce similar teas thus acting as competitors of the Kenyan Tea trade in the global market. Similarly, the traditional markets of Kenyan tea are well established in the global market, making it very difficult for new traders to enter the global markets. As a result, the competitiveness of the Kenyan tea continues to dwindle given that no new demands are created in the traditional markets as the market is already saturated. The existing customers changing preferences and tastes were not accommodated given that Kenyan Tea was exported as a commodity with no value addition and secondly the tea product lack diversification and differentiation which are key aspects of strategic product development practices [10-12]. The exported Kenyan tea product has been the same all through, giving room for customers to switch to competitors products.

Product Life Cycle Theory of International trade was developed by the economist Raymond Vernon in 1966. The theory postulates that products enter the market and gradually disappear due the life cycle of the product. The theory cited the four stages in a product life cycle as introduction, growth, maturity and decline. The theory advised that every product must go through each of the stages and the lifespan of each stage depends on demand, production cost and revenues generated from the product consumption [13]. According to the theory, low production costs and a high demand will ensure a longer product life.

This theory supports the current study in that, the processed Kenyan tea constitute both primary and secondary grades. Each grade command a different market share and price as well. The demand for each grade is also different. The product attributes are static day in day out making it difficult to match the consumer changing needs. Omari [3] found out that, the product life cycle theory asserts that marketing strategies must evolve along with a product from inception through obsolescence. At introduction it involves tailoring marketing mix to spark interest and educate potential customers. At growth phase, efforts shifts to secure a wider audience by building brand loyalty, a stable supply chain and additional distribution channels as defences against competition enter the market. Maturity stage witnesses weaker players driven out and there is little differentiation among competitors. This leads to market saturation leading to eventual decline of the product's market share. Kenyan tea is stocked for long in the warehouses' due to decline in demand. This leads to the said tea being sold below the valuation price at the auction [14-17].

Grant [18] draws on marketing theory and high-tech experience to describe the elements of the product life cycle for technology innovations. Moore examines how communities respond to discontinuous innovations-or any new products or services that require the end user in the marketplace to dramatically change their past behaviour. Moore claimed that companies must position their products differently through the cycle to reach their full sales potential and become an industry standard. Theuri [19] in her study on Strategic Management determinants of Value Addition of Industrial Fish Processors in the Sea Food Processing Sub-chain in Kenya confirmed that Value addition on agricultural products determine the competitiveness of Kenya's produce on world markets.

\section{Methodology}

The research design adopted by this syudy was cross-sectional survey. This design guided qualitative and quantitative data collection from the respondents. The survey design was appropriate because tea industry is a multi-stakeholder industry [20-23]. This study sought to analyse the influence of strategic product development practices on competitiveness of Kenyan Tea in the global market. The target population comprised of all one hundred and eighty nine (189) members of the East Africa Tea Trade Association (EATTA) who participate in the tea auction at Mombasa. To obtain the desired sample size for the study with the organizational population of 189 , Slovin's formula was applied as;

$\mathrm{n}=\mathrm{N} /\left(1+\mathrm{Ne}^{2}\right)$,

Where;

$\mathrm{n}=$ Sample Size

$\mathrm{N}=$ Total Population

e=Error of Tolerance with a confidence level of $95 \%$ (giving a margin error of 0.05 )

$\mathrm{n}=189 /\left(1+189^{\star} 0.05\right)=128.35$ (rounded to 128$)$.

Stratified sampling technique was applied to select the study sample of $68 \%$ of buyers, brokers, warehouse, packers and associate members while purposive sampling technique was used to select KTDA managers who represented small-scale producers and largescale producers [24]. It is advised a $10 \%$ sample of the target population need to be considered an adequate sample for a given study.

This survey explored on the existing conditions or relationships, current processes and the resultant effects in the specific area of study. Inferential conclusions were made from the secondary data from relevant reports. Data acquired was presented and analyzed using SPSS version 22.0. The findings of the study were presented in form of frequency tables [25-27]. The study results were further discussed and interpreted.

\section{Results and Discussion}

The objective of the study was to examine the effect of strategic product development practices on competitiveness of Kenyan Tea in the global market. The study focused on product value addition, product differentiation, diversification, product standardization and certification, lack of patenting and government tax policies as the key strategic product development practices that would impact on competitiveness of Kenyan tea in the global market. According to the respondents as presented in Table 1, 89.3\% of the respondents agreed that low value addition of Kenyan tea affect its competitiveness in the global market. This represents the majority of the respondents. Due to the low value addition according to the respondents, Kenyan tea faces competition from other beverages, consumption rate being too low, and the consumers' preference thus shifting to value added teas from other countries. Consequently, $10.7 \%$ the respondents indicated that with value addition on Kenyan Tea, the resultants would be

\begin{tabular}{|c|c|c|}
\hline $\begin{array}{c}\text { Effect of low value } \\
\text { addition }\end{array}$ & Frequency & Percentage \\
\hline Yes & 300 & 89.3 \\
\hline No & 36 & 10.7 \\
\hline Total & 336 & 100 \\
\hline \multicolumn{2}{|c}{ Table 1: Value addition of Kenyan tea. } \\
\hline
\end{tabular}


increased market base, high prices, high market penetration, improved consumption rate and preference by the consumers and more importantly break the cultural stigma of tea consumption.

Mbui [28] claimed, compared to Kenya, where bulk tea exports are over $90 \%$ of the total, Sri Lanka's bulk exports are lower at about $52 \%$. This results to lower unit earnings from tea exports by Kenya and decline of the Kenyan Tea competitiveness in the global market.

Table 2 represents the respondents' responses rating. The respondents were rated with a Likert scale of 1-5 (where $1=$ Strongly disagree, $2=$ Disagree, $3=$ Neutral, $4=$ Agree, $5=$ Strongly Agree) as presented in Table 2. The Mean in Table 2 represents the average of the Likert scale responses about the influence of Strategic Product Development on competitiveness of Kenyan Tea in the global market. The mean values measures the rating of the respondents; where a mean value between 0.5-1.5 represent strongly disagree,1.6-2.5 disagree,2.6-3.5 Neatral,3.6-4.5 Agree and 4.5-5.5 represented strongly Agree [29-32]

According to the study findings, Kenyan tea has low value addition thus affecting its competiveness in the global market. This observation was supported by a mean of 4.37 . Further the respondents suggested that the low value addition on Kenyan Tea possibly could be improved through flavouring, packaging, branding, product differentiation and diversification [33-38]. The respondents advised that product differentiation would be achieved through processing of speciality teas such as orthodox, purple and green teas while product diversification according to the respondents include extraction of tea by-products [39-42].

The study findings were confirmed in his study of tea value addition in Sri Lanka where he found out that sales in bulk form was a problem that Sri Lanka had to deal with and have now achieved about $45 \%$ tea value addition of her total production compared to Kenya only selling $5 \%$ of tea in value added form. Tea Directorate had a similar observation [43]. MAFAP affirmed that the low value added to tea exports limits farmers' ability to obtain higher prices and respondents were in agreement that up scaling of value addition on Kenyan Tea would enhance its competitiveness in the global market [44]. A mean of 4.41 was recorded to that effect.

Product differentiation as reflected in Table 2 affected competitiveness of the Kenyan Tea in the global market. A mean of 4.34 showed that the respondents were in agreement to this claim. Product diversification promotes consumer preference thus enhancing

\begin{tabular}{|l|c|c|c|}
\hline Strategic Product Development & N & Mean & $\begin{array}{c}\text { Std. } \\
\text { Deviation }\end{array}$ \\
\hline Low Value Addition & 336 & 4.37 & 0.899 \\
\hline Upscaling of Value Addition & 336 & 4.41 & 0.798 \\
\hline Product Differentiation & 336 & 4.34 & 0.607 \\
\hline Product Diversification & 336 & 4.3 & 0.755 \\
\hline Product Standardization and Certification & 336 & 4.36 & 0.719 \\
\hline Lack of patenting & 336 & 3.96 & 1.036 \\
\hline Government Tax Policies & 336 & 4.38 & 0.615 \\
\hline
\end{tabular}

Table 2: Strategic product development descriptive analysis. competitiveness of Kenyan Tea in the global market. The respondents agreed with a mean of 4.30. Product standardization and certification enhances competitiveness of Kenyan Tea in the global market as evidenced by a mean of 4.36 from the respondents [45-48]. In 2012, more tea was certified under the Rainforest Alliance standard than any other voluntary sustainability standard, with 355,297 metric tons of tea certified, representing 7.6 per cent of world tea production and 18 per cent of global exports (Rainforest Alliance, personal communication desk) [49-53]. Further, FAO, in their market report indicated that in 2012, $12 \%$ of global tea production, was considered compliant with a global sustainability standard and Fair-trade International and UTZ Certified have also experienced double-digit growth an indication that Kenyan Tea is meeting international certification standards hence boosting its competitiveness in the global market.

According to the respondents, lack of patenting of the Kenyan Tea promotes blending which reduces its competitiveness in the global market. This was evidenced by an agreement of a mean of 3.96. Government tax policies discourage consumption of Kenyan Tea thus reducing competitiveness in the global market. The respondents were in agreement to this representing a mean of 4.38. The respondents argued that competitiveness of Kenyan tea in the global market was affected by blending of Kenyan tea with other tea of low quality.8.9\% of the respondents reflected a different judgment. Kenya tea exported in bulk to various markets is mostly blended and packed in packages of less than $3 \mathrm{~kg}$ and either sold within importing countries or re-exported for consumption in other countries [47].

The study sought to determine the relationship between strategic product development practices and competitiveness of Kenyan tea in the global market. The results were as indicated in Tables 3 and 4 .

The relationship means that $31 \%$ of the Competitiveness can be explained by Strategic Product development practices. The relationship was not significant at $5 \%$ level of significance $(p=0.440>0.05)$.

According to the study results, competitiveness of Kenyan Tea in the global market was affected by other factors other than strategic product development practices. The study found out that Kenya tea is exported in bulk as a commodity with minimal value addition. This to a great extent contributes to the scenario above where by strategic product development practices leads to a decrease in competitiveness of Kenyan tea in the global market. This further means that modification of the product either through value addition; repackaging, blending or flavouring would not have a significant influence on the competitiveness of the Kenyan Tea in the global market. The findings were in agreement with findings in a study by Mbui [28] on "Effect of Strategic Management Practices on Export Value Addition in the Tea Subsector in Kenya" where study results meant that Kenya mostly dealt with black CTC teas and hence a very narrow product range which in return acted as a hindrance to competitiveness in international markets. The study further informed that in order to ensure effective promotion of tea value addition in export markets, product diversification strategy must be adopted.

The study findings conformed to the study results by Omari [3] on determinants of export performance of Kenya Tea Development

\begin{tabular}{|c|c|c|c|c|c|c|c|c|c|c|}
\hline \multirow[t]{2}{*}{ Model } & \multirow[t]{2}{*}{$\mathbf{R}$} & \multirow[t]{2}{*}{ R Square } & \multirow[t]{2}{*}{ Adjusted R Square } & \multirow[t]{2}{*}{ Std. Error of the Estimate } & \multicolumn{5}{|c|}{ Change Statistics } & \multirow[t]{2}{*}{ Durbin-Watson } \\
\hline & & & & & R Square Change & F Change & df1 & df2 & Sig. F Change & \\
\hline 1 & $.4200^{\mathrm{a}}$ & 0.42 & 0.31 & 1.183 & 0.002 & 0.598 & 1 & 334 & 0.44 & 1.24 \\
\hline
\end{tabular}

Table 3: Model summary. 
Citation: Maina EW, Mugambi F, Waiganjo E (2018) Effect of Strategic Product Development Practices on Competitiveness of Kenyan Tea in the Global Market. Bus Eco J 9: 340. doi: 10.4172/2151-6219.1000340

Page 4 of 5

\begin{tabular}{|l|c|c|c|}
\hline \multirow{2}{*}{ Model } & \multicolumn{2}{|c|}{ Unstandardized Coefficients } & Standardized Coefficients \\
\cline { 2 - 4 } & B & Std. Error & Beta \\
\hline (Constant) & 3.625 & 0.51205 & 7.079 \\
\hline Strategic Product Development & -0.088709677 & 0.115 & $-0.58727 \mathrm{E}-12$ \\
\hline
\end{tabular}

Table 4: Coefficients

Agency managed factories who observed that about $95 \%$ of Kenyan tea production is exported in bulk form which makes it a raw material for further processing. Tea Board of Kenya [54-56] also made a similar view. However, even though the current study findings agree with other researchers' opinions, more emphasis on value addition on Kenyan Tea would increase competitiveness as well as open up new markets. Mbui et al. [47] advised that low value addition on Kenyan tea contributes to lower unit earnings from tea exports by Kenya where bulk tea exports are over $90 \%$ of the total, as compared to Sri Lanka's whose bulk exports were about $52 \%$.

Many researchers as reflected in literature review supported the fact that Tea was the leading foreign exchange earner of the country Kenya thus contributing to the economic development of the country and more so supporting the economic pillar of the Vision 2030. The findings by Omari [3] conforms with Mbui [28] where the majority of the respondents indicated product quality as a major emphasis on tea export market as compared to other product differentiation attributes. This observation support the study results that a change in strategic product development practices results to a unit decrease in competitiveness of Kenyan tea in the global market.

A study conducted at Sri Lanka on Strategies for competitive advantage in value added Tea marketing by Herath and Silva1 [57-62] emphasised on the importance of a change from bulk tea exports to value added tea products to fit in the world tea market which grows rapidly with emerging customer needs and increasing competition from beverage market [63-74].

\section{Conclusion and Recommendations}

The study revealed that strategic Product development practices negatively influences competitiveness of Kenyan Tea in the global market at $5 \%$ level of significance $(\beta 1=-0.089)$. However, this relationship was insignificant $(\mathrm{p}=0.440>0.05)$. According to the study results, it was possible to conclude that competitiveness of Kenyan Tea in the global market was influenced by other factors other than strategic product development.

Kenyan Tea according to the respondents was packaged and sold in bulk as loose tea. This creates room for product manipulation through blending with other teas from other markets. Blending makes the Kenyan tea lose traceability in the global markets. The tea sold in bulk also creates room for the buyer to repackage the tea in smaller quantities. The act of blending and repackaging of the Kenyan tea by the buyers lowers competitiveness of the Kenyan tea in the global market. Respondents indicated that Kenyan Tea lacks branding making it lose traceability in the global markets. Lack of traceability leads to product manipulation which eventually erodes competitiveness.

The consumer's change in tastes and preferences causes Kenyan Tea to slowly lose its competitiveness in the global market given the nature in which Kenyan tea is exported at. Majority of the consumers prefer other ready to drink beverages to tea. The study recommended that the Kenya tea value chain need to come out with innovative ideas for instance ready to drink tea products to counter the escalating global competition. Such products would entice the growing number of youths in many countries. Other than strategic product development practices, the Kenyan industry players should diverge from a long linear supply chain to a value network in order to make Tea a 'hero' crop and enable creation of a more sustainable industry.

\section{References}

1. Jaffee S (1993) Exporting High Value Added Commodities. World Bank Discussion Paper 198, the World Bank, Washington.

2. Atikiya R (2015) Effect of Competitive Strategies on the performance of Manufacturing Firms in Kenya. Jomo Kenyatta University of Agriculture and Technology.

3. Omari IM (2015) Determinants of export performance of Kenya Tea Development Agency managed factories in Kenya. Jomo Kenyatta University of Agriculture and Technology.

4. Atkinson RD (2013) Competitiveness, Innovation and Productivity. The Information Technology and Innovation Foundation, pp: 1-4.

5. Aiginger $\mathrm{K}$ (2006) Competitiveness from a dangerous obsession to a welfare creating ability with positive externalities. Journal of Industrial Trade and Competition 6: 63-66.

6. Barney JB (2002) Strategic management from informed conversation to academic discipline. Academy of Management Executive 16: 53-57.

7. Bellak CJ, Weiss A (1993) A note on the Austrian Diamond. Management International Review 33: 109-118.

8. Bernhofen DM, Brown JC (2004) A direct test of the theory of comparative advantage: The case of Japan. Journal of Political Economy 112: 48-67.

9. Bore JK, Cheserek BC, Ng'eno PK (2011) Long term climate variability and effects on tea yields. Cab Direct 34: 57-67.

10. Brander J, Krugman P (1983) A reciprocal dumping model of international trade. Journal of International Economics 15: 313-321.

11. Brander JA, Spencer BJ (1985) Export subsidies and international market share rivalry. Journal of International Economics 18: 83-100.

12. Budd L, Hirmis AK (2004) Conceptual framework for regional competitiveness. Regional Studies 38: 1015-1028.

13. Chwan-Li S (2012) Green Tea and Bone Health: From Bench to Clinical Tria $5^{\text {th }}$ International Symposium on Tea and Health. U.S. Department of Agriculture Washington, D.C.

14. Kenya Tea Development Agency (2015) Annual Report.

15. Kenya Tea Development Agency (2014) Annual Report.

16. Kenya Tea Development Agency (2013) Annual Report.

17. Kenya Tea Development Agency (2012) Annual Report.

18. Grant RM (1991) Porter's Competitive Advantage of Nations: An assessment. Strategic Management Journal 12: 535-549.

19. Theuri SF (2015) Strategic Management Determinants of Value Addition of Industrial Processors in the Sea Food Processing Subchain in Kenya. Jomo Kenyatta University of Agriculture and Technology.

20. Chemengich MK (2014) Determinants of Competitiveness of Electrical and Electronics Manufacturing Enterprises in Kenya. Jomo Kenyatta University of Agriculture and Technology.

21. Corden WM (1990) Strategic trade policy. How New? How Sensible?

22. Cox D, Harris R (1985) Trade liberalization and industrial organization: Some Estimates for Canada. Journal of Political Economy 93: 114.

23. Davies H, Ellis P (2000) Porter's competitive advantage of nations: time for the final Judgement. Journal of Management Studies 37: 1189-1213.

24. Fendel R, Frenkel M (2005) The international competitiveness of Germany and 
Citation: Maina EW, Mugambi F, Waiganjo E (2018) Effect of Strategic Product Development Practices on Competitiveness of Kenyan Tea in the Global Market. Bus Eco J 9: 340. doi: 10.4172/2151-6219.1000340

Page 5 of 5

other European economies: the assessment of the Global Competitiveness Report. Inter-economics 40: 29-35.

25. Gesimba R (2005) The Tea Industry in Kenya: Challenges and Positive Developments. Journal of Applied Sciences 5: 334-336.

26. Government of Kenya: The Tea Act (CAP 343), Legal Notice No. 132.

27. Grilo I, Koopman G (2006) Productivity and microeconomic reforms Strengthening EU competitiveness. Journal of Industrial Trade and Competition 6: 63-66.

28. Mbui CK (2016) Effect of Strategic Management Practices on Export Value Addition in the Tea Subsector in Kenya. Jomo Kenyatta University of Agriculture and Technology.

29. Grubel HG, Lloyd P (1975) Intra-industry Trade: The Theory and Measurement of International Trade in Differentiated Products. London: Macmillan.

30. Groosma M (2011) Tea Sector Overview. IDH-The Sustainable Trade Initiative.

31. Gurber W, Metha D, Vernon R (1967) The R\&D factor in international trade. Journal of Political Economy 75: 20-37.

32. Harkness J (1983) The factor-proportions model with many nations, goods and factors. Theory and evidence. Review of Economics and Statistics 65: 298.

33. Helpman $E$ (1981) International trade in the presence of product differentiation economies of scale and monopolistic competition. Journal of International Economics 11: 305.

34. Hill C (2008) International Business: Competing in the Global Market Place. Strategic Direction.

35. Kinyanjui S (2015) Response by Kenyan firms to Globalization: A survey of Manufacturing Firms in Nairobi and Athi-River. Jomo Kenyatta University of Agriculture and Technology.

36. Kothari CR (2013) Research Methodology-Methods and Techniques. New Delhi : New Age International Publishers Ltd.

37. Krugman PR, Obstfeld M (2003) International Economics: Theory and Policy. 4th edition. New York: Harper Collins.

38. Krugman $P$ (1983) New theories of trade among industrial countries. American Economic Review 73: 343-347.

39. Krugman PR (1981) Intra-industry specialization and the gains from trade. Journal of Political Economy 89: 959-973.

40. Krugman PR (1980) Scale economies, product differentiation, and the pattern of trade. The American Economic Review. 70: 950-959.

41. Lancaster K (1980) Competition and product variety. Journal of Business 53 S79-S103.

42. Lenore A, Geffen D (2012) Global Association between Tea Consumption and Cardiovascular Disease.

43. Levitt T (1993). Globalization of markets. Harvard Business Review 61: 92-102.

44. Lockett A, Thompson S, Morgenstern U (2009) The development of the resource-based view of the firm: A Critical Appraisal. International Journal of Management Reviews11: 9-28.

45. Lorenz M (2012) Mechanisms of Action of Tea Polyphenols. 5th International Symposium on Tea and Health.

46. Magaziner I, Patinkin (1990) The Silent War. Inside the Global Business Battles Shaping Americas Future. Vintage Books.

47. Mbui CK,Namusonge GS, Mugambi F (2015) Effect of Cost Leadership on Value Addition on Tea Sub-Sector in Kenya. Prime Journal of Business Administration and Management 5: 1936-1940.

48. Mwaura MF, Muku O (2007) Tea Farming Enterprise Contribution to Smallholders' Well Being in Kenya. AAAE Conference Proceedings, pp: 307-313.

49. Nyaga EK, Doppler W (2009) Use of Dynamic Models to Assess Impact of
Changing Tea Prices on Family Income of Smallholders in Kenya. Journal of Applied Sciences.

50. Nyangito H, Kimura J (1999) Provision of Agricultural services in a Liberalized Economy. Food and Agriculture Organization of the United Nations.

51. Nyangito $\mathrm{H}$ (2001) Policy and legal framework for the tea sub sector and the impact on the liberalization in Kenya. Kenya Institute for Public Policy Research and Analysis.

52. Rugman AM, Verbeke A (1990) Global Corporate Strategy and Trade Policy. London New York Routledge.

53. Rugman AM, D'Cruz JR (1993) The double diamond model of international Competitiveness: The Canadian experience. Management International Review 33: 17-32.

54. Tea Board of Kenya (2012) The Tea Market-A background study, Draft for Comments. Nairobi.

55. Tea News Briefs (2010) The Monthly On-Line Newsletter of the Tea Board of Kenya.

56. Tea News Magazine (2014 \& 2015) A quarterly publication of the Tea Board of Kenya.

57. Herath HM, De Silva1 S (2011) Strategies for Competitive Advantage in Value Added Tea Marketing. Tropical Agricultural Research 22: 251-262.

58. Salvatore D (2002) International Economics. New York: Macmillan.

59. Sambasivam T (1996) The future of teas A Sri Lankan Perspective. Tea and Coffee Trade Journal: The international voice of the tea and coffee industries, pp: 38-44.

60. Schott PK (2004) Across-product versus within-product specialization International Quarterly Journal of Economics 119: 647-678.

61. Siggel E (2006) International competitiveness and comparative advantage: A Survey and a Proposal for Measurement. Journal of Industrial Trade and Competition 6: 63-66.

62. Sicily K (2012) Tea News Quarterly publication of the Tea Board of Kenya.

63. Simbua E, Loconto A (2010) Sustainability of Smallholder Tea Production in the United Republic of Tanzania: Proceedings of Commodity Problems Intergovernmental Group on Tea Nineteenth Session. New Delhi, pp: 12-14.

64. Sri Lanka Tea Cluster (2002) A Competitiveness Strategy for Sri Lanka's Tea Industry. Tea Initiative Project.

65. Stone HBJ, Ranchhod A (2006) Competitive advantage of a nation in the globa arena: A quantitative advancement to Porter's diamond applied the UK, USA and BRIC nations. Strategic Change 15: 283-294.

66. Tea Act (2013) Government of Kenya.

67. Tea Research Foundation of Kenya, Strategic Plan (2010-2015).

68. Teece DJ (1996) Firm organization, industrial structure, and technologica innovation. Journal of Economic Behaviour and Organization 31: 193-224.

69. Teece DJ (1998) Research directions for knowledge management. California Management Review 40: 289-292.

70. Thompson ER (2004) National Competitive Advantage and the Roles of Economic and Political Freedom: Evidence from Hong Kong. Public Choice 120: 401-437.

71. Tiampati LS (2013) Kenya Tea Development Agency Holdings Limited Directors Conference.

72. Todd S (2010) Innovation perspectives-managerial innovation critical to the core. Innovation excellence.

73. Asopa VN (2007) Tea Industry of India. India Research and Publications.

74. Waiganjo EW, Mukulu E, Kahiri J (2013) Relationship between strategic human resource management and firm performance of corporate institutions. Jomo Kenyatta University of Agriculture and Technology. 